\title{
$14: 89933126-89944151$
}

National Cancer Institute

\section{Source}

National Cancer Institute. 14:89933126-89944151. NCl Thesaurus. Code C41820.

Physical location of CALM1_Gene 